Niepełnosprawność. Dyskursy pedagogiki specjalnej

\title{
Uzasadnienie potrzeby edukacji seksualnej wśród osób z niepełnosprawnością intelektualną - refleksje na kanwie badań własnych
}

Artykuł porusza tematykę seksualności osób z niepełnosprawnością intelektualną w kontekście edukacyjnym. Proponuje spojrzenie na problem istnienia potrzeby działań edukacyjnych w tym zakresie, skierowanych pośrednio także do rodziców/opiekunów oraz środowiska społecznego. Zawiera zarys perspektyw „uzasadniania” seksualności osób z niepełnosprawnością intelektualną, próbę ukazania sensu edukacji seksualnej oraz wyniki badań własnych, dotyczących doświadczania seksualności przez osoby z orzeczeniami o niepełnosprawności intelektualnej w stopniach znacznym i głębokim.

Słowa kluczowe: edukacja seksualna, rozwój psychoseksualny, niepełnosprawność intelektualna

\section{Justifying the need of sexual education of people with intellectual disability - reflection in the context of the own research}

This article is devoted to sexuality of people with intellectual disabilities in the educational context. The author points out the need of sexual education developed not only for the intellectually disabled ones, but also for parents/carers and the social environment. It outlines the concepts of "justifying" the sexuality of persons with intellectual disabilities as well attempts to show the legitimacy of sexual education. In the paper the author discusses findings of her research on the experiences of sexuality by persons with severe and profound intellectual disability.

Keywords: sexual education, psychosexual development, intellectual disability

\section{Kilka słów wprowadzenia}

Do niedawna, tematyka seksualności osób z niepełnosprawnością intelektualną była społecznym tabu. Zarówno w świadomości badaczy, jak i społecznej percepcji tego zagadnienia, jawiła się ona jako nieodkryty, niewiadomy, czy zaprzeczany obszar rozwoju. Mimo rosnącej liczby eksploracji naukowych, nadal określana jest jako „seksualność trudna” [por. Kijak 2011; Kościelska 2004], głów- 
nie ze względu na wielość czynników, które warunkują prawidłowy jej rozwój, braki w edukacji seksualnej, specyfikę funkcjonowania osób z niepełnosprawnością intelektualną, czy społeczny obraz tego zagadnienia (nadal pełen mitów i stereotypów).

\section{Potrzeba społeczna...?}

$\mathrm{W}$ oddziaływania pedagogiczne wpisana jest nieodłącznie pedagogizacja, współpraca ze środowiskiem ( $w$ tym z rodziną), a także edukacja społeczna w celu uświadamiania, wypełniająca ramy profilaktyki uniwersalnej, selektywnej i wskazującej. Zatem zadaniem pedagogów specjalnych i osób zajmujących się edukacją oraz wspieraniem staje się walka z mitami i stereotypami, które nadal silnie osadzone są w świadomości społecznej, a ich skutkiem jest osłabienie możliwości rozwojowych osób z niepełnosprawnością intelektualną [Janiszewska-Nieścioruk 2013, s. 254-257].

Obecność mitów i stereotypów dotyczących sfery seksualnej osób z niepełnosprawnością kreuje cały wachlarz postaw, także u rodziców/opiekunów - od infantylizacji (wieczne dzieci, aseksualizm - brak zdolności do odczuwania) po demonizację (hiperseksualizm - kompulsywna seksualność, seksualność dewiacyjna) [por. Kościelska 2004; Kijak 2011; Janiszewska-Nieścioruk 2013]. Fakt braku przyzwolenia na psychoseksualny rozwój dzieci, obrazują badania, w wyniku których ustalono, że zaledwie 3,8\% rodziców akceptuje to, że ich dzieci z niepełnosprawnością stają się w pewnym momencie istotami seksualnymi, z kolei aż 37,4\% przyjmuje wobec tego faktu postawę odrzucenia [Kijak 2014].

Prócz obecności „mitologii seksualnej” w przekazie społecznym, prawdziwy obraz seksualności zakłóca brak wiedzy na temat psychoseksualnego rozwoju człowieka, w tym specyfiki funkcjonowania osób z niepełnosprawnością intelektualną. Natomiast istniejące wyniki badań jednoznacznie wskazują, na istnienie wymiaru seksualnego, który w aspekcie biologicznym najmniej różni się od rozwoju człowieka pełnosprawnego. $Z$ doniesień badawczych wynika bowiem, że osoby z niepełnosprawnością intelektualną:

- identyfikują się ze swoja płcią, począwszy od okresu adolescencji przeżywają potrzebę seksualną, maja pragnienia i marzenia seksualne [Kijak 2010];

- wykazują zainteresowanie osobami płci przeciwnej oraz zróżnicowanie w zakresie preferencji seksualnej [Kościelska 2004];

- rozwój bioseksualny przebiega według wzorów rozwojowych, podobnych do tych u osób pełnosprawnych [Mejnartowicz 2002]; 
- rozwój ten rozpoczyna się nieco później - tym później, im głębszy stopień niepełnosprawności [Kijak 2010];

- mają wrodzony popęd seksualny, prawidłowe wydzielanie hormonów rozrodczych [Jaczewski, Radomski 1986];

- są zdolne do przeżywania orgazmu [Kijak 2010];

- wykazują zainteresowanie tematyką seksualności, mają pewną wiedzę na jej temat, jednak jest ona często fragmentaryczna i niewystarczająca [Leutar, Mihokovic 2007];

- nie ma zasadniczych różnic w częstotliwości występowania masturbacji w porównaniu z osobami pełnosprawnymi [Fornalik 2002].

Aktualny stan wiedzy, ukazuje również obszar niedomagań w zakresie rehabilitacji psychoseksualnej i podejścia do rozwijania tej sfery u osób z niepełnosprawnością intelektualną. Wnioski są następujące:

- brak wiedzy socjoseksualnej wśród osób w każdym wieku,

- segregacja seksualna - wyrażająca się zarówno w sposobach opieki instytucjonalnej, jak i warunkowana kulturowo (np. „ideał” człowieka kreowany przez media, w którym nie ma miejsca dla „upośledzeń"),

- niespójność zasad obowiązujących w ośrodkach/placówkach i domu, jak i w interakcjach społecznych (większe przyzwolenie na realizowanie swojej seksualności przez osoby pełnosprawne),

- brak intymności, w tym podmiotowego podejścia, ograniczanie autonomii [Kościelska 2004].

\section{Perspektywy „uzasadnienia” seksualności osób z niepełnosprawnością intelektualną}

Edukację i poszerzanie świadomości społecznej, w tym rodzicielskiej, warto rozpoczynać od ukazania dowodów i przedstawienia argumentów na istnienie rozwoju psychoseksualnego u osób funkcjonujących w obszarze wszystkich stopni niepełnosprawności intelektualnej. Poniżej nakreślono zarys perspektyw, które ukazują podstawy właściwego rozumienia seksualności człowieka.

\section{Perspektywa biopsychospołeczna}

Fundamentem „uzasadniania” seksualności i potrzeby edukacji seksualnej, jest szerokie rozumienie tego pojęcia. Należy odnosić je do różnych aspektów życia człowieka: sfery fizycznej, emocjonalnej, poznawczej, społecznej i interpersonalnej. W każdym zakresie istnieją bowiem jej przejawy. Pozbawianie seksualności osoby z niepełnosprawnością intelektualną, wynikać może z redukcjo- 
nistycznego podejścia - takiego, które istotę tej sfery sprowadza do wymiaru fizycznego (seksualność utożsamiana z wąsko rozumianym seksem). Rozmowy o odcieniach miłości (przyjacielskiej, partnerskiej, rodzinnej...), higienie osobistej, identyfikacji płciowej, atrybutach płci, rolach społecznych i funkcjach rodziny, także powinny wypełniać treści zajęć z zakresu edukacji seksualnej.

Płciowość - seksualność stanowi jedną z wielu sfer funkcjonowania człowieka, zależną od pozostałych i niemożliwą do wyizolowania. Rozwój psychoseksualny następuje, bez względu na to, czy damy na niego nasze społeczne, rodzicielskie przyzwolenie. Dążenie do optymalnych możliwości osoby, wpierania jego potencjału, warunkuje, między innymi, jak największa harmonijność rozwoju, nie sposób pomijać więc (zaprzeczać, wypierać istnienie) jednej ze sfer. Tym bardziej, jeśli jest to właśnie seksualność, której elementy - jak wspomniano - ujawniają się w pozostałych obszarach funkcjonowania człowieka.

\section{Perspektywa personalistyczna}

Doświadczenia z obcowania i współpracy z rodzicami/opiekunami, dyskusje ze studentami i środowiskiem społecznym, wskazują, że w „uzasadnianiu” seksualności osób z niepełnosprawnością intelektualną, nie sposób pomijać perspektywy moralno-duchowej. „Tu zarówno zgoda społeczna przesuwa się wprawdzie w stronę normalizacji warunków życia, jednak wyrażanie zatrzymuje się przed takimi atrybutami dorosłości, jak: macierzyństwo, małżeństwo, posiadanie potomstwa, życie seksualne. Liczne publikacje dokumentują przejawy społecznej hipokryzji, funkcjonujących stereotypów i marginalizacji problemów związanych z tymi obszarami. Brak koedukacyjności ośrodków, segregacja fizyczna płci (inne piętra, budynki), opór w realizowaniu nowych koncepcji i skostniałe ustalenia $\mathrm{w}$ praktyce pedagogicznej (regulaminy, nieistniejące regulacje i mechanizmy wsparcia związków partnerskich), przekonanie o nadpobudliwości seksualnej tej grupy osób, niezdolności do trwałych związków itd. stawiają nas poza światem cywilizowanym w tej materii" [Krause 2009, s. 16]. Do wymienionych czynników można dodać także strach przed seksualnym „rozbudzeniem” w toku edukacji, brak podmiotowego postrzegania osób z niepełnosprawnością i rozumienia ich dorosłości (osadzenie w mentalności traktowania tych osób, jako „wiecznych dzieci").

Drogę do zmiany w tym zakresie, może otwierać perspektywa personalistyczna, której reprezentantem jest ksiądz prof. dr hab. Antoni Bartoszek. Jako wieloletni praktyk w procesie wspierania osób z niepełnosprawnością intelektualną, przekonuje, że „człowiek niepełnosprawny, jak każda inna istota ludzka, jest jednością duchowo-psychofizyczno-cielesną, ma on także prawo do dojrzałego i pogłębionego przeżywania własnej seksualności”, i dalej: „człowiek niepełno- 
sprawny, będąc bądź też mężczyzną, bądź też kobietą, zachowuje swoją osobową godność niezależną ani od płci, ani od niepełnosprawności" [2009, s. 76-77]. Jest piewcą podmiotowego traktowania człowieka, niezależnie od stanu, w jakim funkcjonuje i ograniczeń, jakie posiada. W swoich poglądach, o seksualności osób z niepełnosprawnością intelektualną, wyraża się, jako darze i zadaniu.

\section{Sens edukacji seksualnej osób z niepełnosprawnością intelektualną}

W literaturze wyróżniono fazy rozwoju psychoseksualnego człowieka (seksualność dziecięca, młodzieńcza, dojrzała oraz starcza), które u osób z niepełnosprawnością intelektualną mogą przebiegać w specyficzny sposób [Kościelska 2004; Fornalik 2007]. Najczęściej:

- mogą pojawiać się z opóźnieniem w stosunku do wieku, bywają też niewłaściwie ukierunkowane;

- przechodzą przez dane etapy w sposób niepełny lub też odwrotnie - w sposób nadmiernie zaznaczony;

- zdarza się również, że zatrzymują się na dłużej (lub nawet na stałe) w jakiejś $\mathrm{z}$ faz;

- występuje tzw. „spóźniona” seksualność dziecięca [Kościelska 2004] - w wyniku deprywacji potrzeb i zaniedbań edukacyjnych.

Zmieniony kształt procesu dojrzewania psychoseksualnego, generuje potrzebę doboru swoistych treści edukacyjnych (nierzadko rozszerzonych jak np. w przypadku bloku "Higiena osobista”) i trafnego określenia czasu, form (często opartych o systematyczne powtarzanie nabytych wiadomości i umiejętności) oraz metod oddziaływań. Niewątpliwie, uzasadnia także potrzebę prowadzenia edukacji seksualnej wśród osób z każdym stopniem niepełnosprawności intelektualnej.

Sens tych działań wyraża się w akceptacji zmian zachodzących w poszczególnych fazach rozwoju psychoseksualnego oraz niwelowaniu niepokoju, który może im towarzyszyć (pierwsza menstruacja, wzrost piersi, polucje nocne, zarost, „burza hormonalna” itp.). Zadaniem edukacji seksualnej, jest zatem wprowadzenie rzetelnej i dostosowanej do poziomu rozumienia wiedzy; pokazanie, że zachodzące zmiany są naturalne. Podczas zajęć, osoby z niepełnosprawnością intelektualną, mają szansę na zaznajomienie się z prawidłowym nazewnictwem dla określania własnej seksualności (budowa ciała, narządów płciowych, nazywanie potrzeb, emocji), gdyż często wiedzę na ten temat czerpią z alternatywnych źródeł (Internet, telewizja, grupa rówieśnicza) lub są pozbawieni tej możliwości, ze względu na ograniczenia poznawcze, minimalną sieć społeczną, brak zaufanych osób wspierających [Buchnat, Waszyńska 2014]. 
Edukacja seksualna ma bardzo istotną rolę w profilaktyce medyczno-zdrowotnej. Prócz uposażania w wiedzę na temat chorób wenerycznych i chorób narządów płciowych, ćwiczeniu umiejętności asertywnej ochrony przed przemocą seksualną, czy zagadnień związanych z nawykami higieny osobistej i jej znaczeniu dla zdrowia, przywiązuje się wagę do - często zaniedbywanych profilaktycznych badań ginekologicznych i urologiczno-andrologicznych [por. Kijak 2011]. Potrzebę tę potwierdzają doniesienia naukowe [por. McGillivray 1999; Buchnat, Waszyńska 2014], które prowadza do wniosków, że młodzi ludzie z niepełnosprawnością w stopniu lekkim i umiarkowanym, w porównaniu z populacją osób pełnosprawnych w tym samym wieku, maja większy deficyt wiedzy ogólnej o zagrożeniach np. HIV/AIDS, sposobach minimalizowania niebezpieczeństwa zakażenia, jak również mniej adaptatywną postawę w stosunku do AIDS, szczególnie w odniesieniu do używania prezerwatyw. Cechuje ich także mniejsza wiara we własną zdolność stosowania praktyk bezpieczniejszego seksu.

Edukacja seksualna, jak każde inne działania o charakterze rehabilitycyjnowychowawczym, powinny mieć także wymiar pedagogizacyjny w stosunku do rodziców/opiekunów. Równolegle z zajęciami dla osób z niepełnosprawnością intelektualną, należy prowadzić cykle spotkań/warsztatów dla rodziców, których celem jest zarówno uświadamianie, zapoznawanie z wynikami najnowszych badań naukowych, ćwiczenie umiejętności, jak i nawiązanie efektywnej współpracy w zakresie wspierania rozwoju psychoseksualnego podopiecznych. Pozwoli im to zrozumieć potrzeby seksualne swoich dzieci i nie obawiać się przejawów ich seksualności, a wręcz przeciwnie - będą skłonni udzielić im odpowiedniej pomocy. Takie programy można organizować, bądź jako samodzielne bloki dla rodziców, bądź wspólnie z dziećmi, a zwłaszcza podczas obozów wakacyjnych. Sukces pedagogiczny gwarantuje bowiem, system jednolitych zasad, stosowanie tożsamego języka, poszanowanie intymności rozumiane w podobny sposób, konsekwencja zachowań, ustalenie wspólnych celów oddziaływań, nie wyłączając oczywiście potrzeb i oczekiwań samych zainteresowanych.

Podstawowy kurs edukacyjny z zakresu seksualności osób z niepełnosprawnością intelektualną, powinien przejść także personel opiekujący się osobami ze specjalnymi potrzebami, także wówczas, gdy nie będzie bezpośrednio szkolił swoich podopiecznych w tej tematyce. McCarthy i Thomson [1997] przydatność takiego warsztatu upatrują w tym, że personel:

- bardziej uświadomi sobie, że podopieczni są istotami seksualnymi, a ich seksualność w zasadzie nie różni się od seksualności każdego z nas,

- będzie chętniej wspierał i umożliwiał edukację seksualną,

- nie będzie w takim stopniu, jak dotychczas, obawiał się konsekwencji ich życia seksualnego, 
- będzie lepiej poinformowany o odrębnościach dotyczących wzajemnych kontaktów partnerskich i seksualności osób z niepełnosprawnością intelektualną, które różnią się od jego własnych doświadczeń,

- będzie następnie upowszechniać optymalne strategie (politykę zdrowotną) i sposoby pracy z osobami z niepełnosprawnością intelektualną $\mathrm{w}$ zakresie seksualności, a tam gdzie ich jeszcze nie ma, wskaże na konieczność ich stworzenia,

- zwiększy wiarę w siebie, gdyby w przypadku takiej potrzeby podjął się wychowania seksualnego ludzi ze specjalnymi potrzebami.

Jednak najważniejsza jest edukacja seksualna samych osób z niepełnosprawnością intelektualną. Jednym z podstawowych warunków pracy, jest włączanie ich do grup nauczania, zgodnie z aktualnym stanem rozwoju poznawczego, społecznego i biologicznego, a nie według ich fizycznego wieku lub klasy szkoły, do której uczęszczają. Zgodnie z wytycznymi "Standardów edukacji seksualnej w Europie" [2012], ma ona być wielowymiarowa, obejmować obszar kognitywny, emocjonalny, społeczny i fizyczny. Powinna ona rozpoczynać się we wczesnym dzieciństwie i być kontynuowana przez całe życie. Głównym celem, który ma jej przyświecać uczyniono: wspieranie i ochronę rozwoju psychoseksualnego, ma umożliwiać zdobycie informacji, umiejętności, budowanie wartości, zrozumienie i „oswojenie" seksualności (także w trakcie pedagogizacji rodziców). Podkreśla się w niej prawo do edukacji, które przysługuje wszystkim ludziom, bez względu na stan, w jakim funkcjonują i towarzyszące mu ograniczenia.

\section{Badania własne}

\section{Metodologia}

Badaniami objęto 13 dorosłych osób z niepełnosprawnością intelektualną w stopniu znacznym i głębokim ${ }^{1}$ (5 kobiet i 8 mężczyzn) - uczestników zajęć Świetlicy Terapeutycznej w wieku 26-61 lat, których rodzice i/lub terapeuci określili brak edukacji seksualnej $w$ toku życia. Wywiad przeprowadzono w placówce, przy obecności dwóch terapeutów, którzy uczestniczyli w wywiadzie, jako osoby wspomagające badacza (ich rola polegała na doprecyzowaniu pytań badacza do indywidualnych możliwości komunikacyjnych osób badanych).

1 Informacje o stopniu niepełnosprawności intelektualnej, osób biorących udział w badaniu, zostały zaczerpnięte z formalnej dokumentacji uczestników świetlicy. Warto nadmienić, że orzeczenia często pochodziły sprzed kilku dekad, a poziom realnego funkcjonowania - nie tylko intelektualnegobył znacząco wyższy, niż sugeruje to diagnoza zawarta w dokumentacji tych osób. 
Badania osadzono na gruncie metodologii jakościowej, realizując ją metodą fenomenograficzną. Zakłada ona istnienie znaczeń i konotacji dla otaczającej rzeczywistości spostrzeganych subiektywnie, co stanowi osobisty wymiar rozumienia świata. „Sposób nadawania znaczeń zjawiskom, pojęciom, jest związany z jednostkową wiedzą o świecie, a zarazem charakteryzuje kulturowy kontekst interpretacji zjawiska przez jednostkę" [Pilch, Bauman 2001, s. 304]. W badaniu zastosowano technikę wywiadu fokusowego semi-ustrukturyzowanego (zogniskowany wywiad grupowy). Wybór ten podyktowany był specyfiką funkcjonowania placówki i istniejącej w jej ramach grupy osób z niepełnosprawnością intelektualną. Wywiad fokusowy umożliwił zebranie materiału do analiz, w możliwie krótkim czasie, tak by znacząco nie zakłócać rytmu dnia uczestników i zapewnić komfortową bliskość osób, z którymi czują się bezpiecznie (innych uczestników i terapeutów). Sprawiło to, że osoby badane wypowiadały się chętniej i mogły odnosić swoje wypowiedzi do innych osób, co ułatwiało im werbalizację, a badaczowi lepsze zrozumienie przekazywanych treści (np. osoby wskazywały w swojej grupie przedstawicieli płci przeciwnej, opisywały powody sympatii do konkretnego człowieka).

Przedmiotem zainteresowania fenomenografii jest zatem sposób w jaki ludzie doświadczają zjawisk, albo różne sposoby doświadczania tego samego zjawiska. W tym przypadku uczyniono nim doświadczanie i rozumienie własnej seksualności przez dorosłe osoby ze znacznym i głębokim stopniem niepełnosprawności intelektualnej. Celem badań, jest ukazanie swoistości doświadczania psychoseksualnego osób z niepełnosprawnością intelektualną, by umożliwić adekwatny dobór treści edukacji seksualnej i uzasadnić jej potrzebę. Sposób, w jaki doświadczanie jest opisywane nie należy do świata zjawisk fizycznych, czy psychologicznych, a jest raczej rodzajem indywidualnej relacji pomiędzy człowiekiem, a zjawiskiem seksualności.

Procedura postępowania badawczego znajduje swoje odzwierciedlenie w języku fenomenografii. Przedmiotem analiz fenomenograficznych jest tekst, będący rekonstrukcją wypowiedzi zgrmomadzonych metodą semi-ustrukturyzowanego wywiadu grupowego. Dobór grupy był celowy. Obejmowała ona dorosłe osoby z niepełnosprawnością intelektualną - uczestników Świetlicy - które posiadały umiejętność komunikacji werbalnej lub wspierana ona była metodami komunikacji alternatywnej (piktogramy) oraz wyraziły zgodę na udział w badaniu.

W czasie przeprowadzania wywiadu odwoływano się do doświadczeń podmiotu w zakresie zjawisk, o których rozumienie pytano. Dlatego formuła pytań fenomenograficznych $\mathrm{w}$ rozmowie ma postać: Czym jest dla ciebie dane zjawisko? Co to znaczy według ciebie? Czy możesz to wyjaśnić? Jak to zjawisko odkrywasz? Co ten problem znaczy dla Ciebie? Prośba badacza o objaśnianie, uzupełnianie, roz- 
winięcie wypowiedzi $w$ trakcie nagrywania rozmowy jest nieodłącznym elementem stosowanej procedury [Marton 1986].

Analiza danych

Analiza tekstu wypowiedzi zgodnie z przedstawioną powyżej procedurą, opisującą sposób postępowania badacza oraz przedstawiającą przejście - od kilkukrotnego czytania transkrypcji wywiadów - do nakreślenia przestrzeni wynikowej, w rezultacie pozwoliła wyłonić kategorie opisu doświadczania seksualności $\mathrm{w}$ świadomości dorosłych osób z niepełnosprawnością intelektualną $\mathrm{w}$ stopniu znacznym i głębokim. Te - jak się okazało - tworzą dosyć jednorodną pod względem znaczenia jakość. Oto szczegółowe kategorie opisu, ujawniające kategorie rozumienia seksualności, wypowiedziane przez badanych, a nazwane językiem badacza:

A. seksualność jako wyraz emocjonalnej bliskości,

B. seksualność jako identyfikacja płciowa wraz z jej atrybutami,

C. seksualność w kontekście orientacji seksualnej,

D. seksualność wyrażana w rozumieniu intymności,

E. seksualność jako potrzeba fizycznego rozładowania związana ze wstydem.

A. Seksualność jako wyraz emocjonalnej bliskości

Jest to kategoria, która pojawiała się w kontekście indywidualnego doświadczania miłości (głównie rodzinnej), przyjaźni i sympatii do innych osób obojga płci. Tę kategorię tworzą następujące fragmenty wypowiedzi:

„lubię i kocham panią Ewę (...), tańczymy, tuli i opowiada" - o terapeutce, kobieta, 26 lat, "kocham mamusię, mamuuusiaa, [cmokanie] przytula, gdzie jest moja mamusia?" kobieta, 37 lat,

„mam dziewczynę i byliśmy w kawiarni i piwo czasem pijemy, bo się lubimy i kochamy i potrzebujemy, (...) sam z nią chodzę, ale do kawiarni idzie z nami mama albo tata, będzie z tego coś więcej”, ",miałem też inne dziewczyny, ale to nie była miłość, to nie było to, teraz się kochamy" - mężczyzna, 39 lat,

„najbardziej lubię wszystkich tutaj, a najbardziej ich [Agatę i Rafała], razem śpiewamy i są mi potrzebni codziennie, jak wychodzimy to idziemy we trzech w parze (śmiech), ale Rafał trudno chodzi, a ja mam wózek, pomagamy nam, i Agata mi i ja czasem też, nie? (...) wiem, że ich lubię, bo myślę o nich $\mathrm{w}$ domu i opowiadam mamie, że było dzisiaj fajnie i byliśmy razem, (...) smutno mi jak nie ma jego [pokazuje Rafała] i Agaty, bo wtedy nie jest fajnie i mnie też mogli nie prowadzić" - kobieta, 28 lat.

Czasem jawi się jako wyraz tęsknoty za osobami, których z różnych przyczyn już nie ma:

„kochałem moją mamusię, już jej nie ma, patrzy na mnie z góry” - mężczyzna, 61 lat, 
„chciałam, żeby pani Ania się nie wyprowadziła, bo kochałam ją najbardziej, ona mnie przytulała i głaskała" - kobieta o swojej opiekunce, 34 lata.

B. Seksualność jako identyfikacja płciowa wraz z jej atrybutami

W trakcie badania ujawniono, że większość rozmówców nie posiada identyfikacji płciowej, lub często jest ona niejasna (kobieta, lat 34, twierdzi, że jest „dziewczynką”, ale nie „kobietą”, ani nie „panią”; mężczyzna, lat 42, zna atrybuty płci, jednak pytany, odpowiada, że jest „dziewczynką”, ludzi obojga płci, określa jako „dziewczynki”). Pozostali uczestnicy swoją seksualność doświadczają poprzez pryzmat własnej płci i jej atrybutów. Częściej, w dokładniejszy sposób opisywali swoje cechy, aniżeli płci przeciwnej.

„Jestem mężczyzną. Mam brodę i wąsy, nie widać ich, bo codziennie się golę, czasem pomaga Jurek”, „Mężczyźni są silni, jak ja i pracują, mają spodnie i koszulę, jak dyrektor" - mężczyzna, 61 lat.

„Mam kolczyki i długie włosy, jestem ładna, kobiety malują się szminką, ja nie, tylko czasem, jak pozwoli mama" - kobieta, 27 lat.

„Kobiety i dziewczynki mają sukienki, ja nie mam. Mam spodnie i buty płaskie. Pomagam w domu i wyrzucam śmieci. Znam się na autach i będę policjantem. Kobiety rodzą dzieci i mają mężów, nie żony" - mężczyzna, 38 lat.

„Pani jest baba, bo baba to baba, a chłop to chłop!” - mężczyzna, 27 lat.

C. Seksualność w kontekście orientacji seksualnej

Kategoria ta została wyróżniona, jako odrębna w badaniu, gdyż pomimo trudności z identyfikacją płciową, uczestnicy w większości opisywali doświadczanie własnej orientacji seksualnej - istnieją wyraźne "tropy”, które można potraktować jako próby jej samookreślenia. Wyrazem jej jest najczęściej „podobanie się”, zmysłowe i emocjonalne doznania, ujawniające się w werbalnej i pozawerbalnej komunikacji.

„Podoba mi się Michał, on jest ładny i ja jestem ładna” - kobieta, 28 lat.

„Moja dziewczyna pięknie pachnie, tak jak pani” - mężczyzna, 39 lat.

„Podoba mi się Agata i pani Patrycja jest ładna. Ma ciemne włosy, nosi ładne sukienki, pani jest ładna, ale ma męża" - mężczyzna, 42 lata.

„Mmm! (podskakuje na krześle) jest jedna pani, mi się podoba, ale nie powiem! Jest bardzo ładna! Bardzo!" - mężczyzna, 37 lat.

D. Seksualność wyrażana w rozumieniu intymności

Doświadczaniu własnej intymności uczestników, towarzyszy brak świadomości prawa do jej poszanowania. Niektóre z wypowiedzi mogą być reprodukcją komunikatów usłyszanych od rodziców/opiekunów. Natomiast wyraźnie uwi- 
dacznia się potrzeba prywatności, zgłaszana nader jasno przez niemal wszystkie osoby.

"Chciałbym być sam czasem ze swoja dziewczyną, ale mama pogoni" - mężczyzna, 39 lat.

„Janka (osoba, która sprawuje opiekę) nie lubi się przytulać. Ja się przytulam do pań tutaj, tańczę i całuję w rękę. Nie chcę żony, bo będę miał spokój! - mężczyzna, 61 lat.

„Siku chodzę z kimś, nie sama. A ja umiem sama! Chcę sama!" - kobieta, 37 lat.

„Podpaskę zmieniam. I umiem, tylko powiem. Mogę iść z kimś, obojętnie z kim. Nie lubię wtedy, jak ktoś jest. Wolę sama" - kobieta, 28 lat.

"Jak idę do toalety, to trzeba komuś powiedzieć. Ktoś musi popatrzeć, żeby nie było niespodzianki" - mężczyzna, 26 lat.

E. Seksualność jako potrzeba fizycznego rozładowania związana ze wstydem

Kategorię tę ujawniono tylko w jednym przypadku, jednak okazała się ona ważna w perspektywie doświadczania własnej seksualności. Mężczyzna, który swoją seksualność traktuje także jako potrzebę fizyczną, nieodłącznie wiąże ją ze wstydem, który wyraża w formie werbalnych komunikatów i pozawerbalnie.

„Czasem idę do toalety, jak mi się pani podoba... (głowę spuszcza w dół), ale myję ręce! Nikomu o tym nie mówię...nie wolno...ale muszę (smutna mina towarzyszy wypiekom na twarzy). Nie lubię, Ty powiedz (wskazuje terapeutkę), ja nie powiem!" - mężczyzna, 37 lat.

Poniższa tabela prezentuje wyodrębnione $\mathrm{w}$ tym konkretnym badaniu konteksty i domeny opisu, dzięki którym - w toku analizy badawczej - wyłoniono kategorie opisane szerzej powyżej. Oczywiście, otrzymane wyniki badań i subiektywnie wyłonione kategorie, nie mogą być uogólnione w tej populacji, jednak mogą stanowić przyczynek do pewnego rodzaju śmiałości badawczej w odkrywaniu seksualności osób ze znaczną i głęboką niepełnosprawnością intelektualną. Otrzymane wyniki sugerują również potrzebę naukowego i praktycznego zainteresowania się tą tematyką wśród osób z tej populacji.

W świetle prezentowanego podejścia fenomenograficznego można zauważyć, że osoby z niepełnosprawnością intelektualną, opowiadając o własnym doświadczaniu seksualności, identyfikują je z codziennym funkcjonowaniem. Relacjonując "to, co jest", nakładają na własne doświadczanie zjawiska - pewne schematy, które osadzone są $\mathrm{w}$ określonych środowiskach (rodzinnym, instytucjonalnym, rzadko społecznym). Jednym z zarzutów, jaki formułują krytycy podejścia fenomenograficznego jest to, że badacze nie poddają analizie mechanizmów produkcji wiedzy i jej reprodukcji przez badane podmioty. Natomiast ważne jest, że rodzaj doświadczania zjawiska czy sytuacji, dotyczy jednocześnie sposobu „wytwarzania” znaczenia w konkretnym czasie, w określonej przestrzeni 
społeczno-kulturowej [Marton 1986]. W tym sensie, można sądzić, że na obecną chwilę, badane osoby z niepełnosprawnością intelektualną, nie wyobrażają sobie innego doświadczania własnej seksualności, aniżeli ta, którą opisali „tu i teraz". Obraz nosi znamiona ograniczeń rozwoju sfery seksualnej, jednak pozostaje pytanie: na ile warunkowane są one poprzez niepełnosprawność?, oraz: na ile brak edukacji psychoseksualnej wpłynął na doświadczanie własnej seksualności?

Tabela 1. Konteksty, domeny i kategorie opisu badań

\begin{tabular}{|c|c|c|c|c|c|}
\hline $\begin{array}{l}\text { KONTEKSTY } \\
\text { wynikające } \\
\text { z kondensacji } \\
\text { fragmentów } \\
\text { tekstu, grupo- } \\
\text { wania i po- } \\
\text { równywania } \\
\text { wypowiedzi }\end{array}$ & $\begin{array}{l}\text { - indywidual- } \\
\text { ne doświad- } \\
\text { czanie miłoś- } \\
\text { ci (otrzymy- } \\
\text { wanie i ob- } \\
\text { darzanie nią) } \\
\text { - formy okazy- } \\
\text { wania bli- } \\
\text { skości emo- } \\
\text { cjonalnej }\end{array}$ & $\begin{array}{l}\text { - forma zastana, } \\
\text { oparta na } \\
\text { zdobytych } \\
\text { wiadomoś- } \\
\text { ciach } \\
\text { - słabe poczucie } \\
\text { tożsamości } \\
\text { płciowej } \\
\text { przy dużej } \\
\text { znajomości } \\
\text { atrybutów } \\
\text { płci i typo- } \\
\text { wych ról } \\
\text { społecznych }\end{array}$ & $\begin{array}{c}\text { - sensualne do- } \\
\text { znania zwią- } \\
\text { zane z kon- } \\
\text { taktem z in- } \\
\text { nymi osobami } \\
\text { - różnorodne } \\
\text { cechy atrak- } \\
\text { cyjności }\end{array}$ & $\begin{array}{l}\text { - ograniczone } \\
\text { doświadcza- } \\
\text { nie prywat- } \\
\text { ności } \\
\text { - istotność } \\
\text { prawa do in- } \\
\text { tymności } \\
\text { - komunikaty } \\
\text { o charakterze } \\
\text { wyuczonych } \\
\text { wskazówek }\end{array}$ & $\begin{array}{l}\text { - stosowanie } \\
\text { kar i nagród } \\
\text { - poczucie za- } \\
\text { kłopotania } \\
\text { w związku } \\
\text { z odczuwa- } \\
\text { niem popędu }\end{array}$ \\
\hline $\begin{array}{l}\text { DOMENA } \\
\text { OPISU - } \\
\text { kryterium } \\
\text { różnicujące }\end{array}$ & $\begin{array}{l}\text { istnienie pot- } \\
\text { rzeby i wyra- } \\
\text { żanie miłości } \\
\text { w różnych jej } \\
\text { odcieniach }\end{array}$ & $\begin{array}{l}\text { tożsamość } \\
\text { płciowa }\end{array}$ & gusta & $\begin{array}{l}\text { istnienie } \\
\text { potrzeby } \\
\text { intymności }\end{array}$ & $\begin{array}{l}\text { nieuniknioność, } \\
\text { istnienie popę- } \\
\text { du seksualnego }\end{array}$ \\
\hline $\begin{array}{l}\text { KATEGORIE } \\
\text { OPISU }\end{array}$ & $\begin{array}{l}\text { seksualność } \\
\text { jako wyraz } \\
\text { emocjonalnej } \\
\text { bliskości }\end{array}$ & $\begin{array}{l}\text { seksualność } \\
\text { jako identyfi- } \\
\text { kacja płciowa } \\
\text { wraz z jej } \\
\text { atrybutami }\end{array}$ & $\begin{array}{l}\text { seksualność } \\
\text { w kontekście } \\
\text { orientacji } \\
\text { seksualnej }\end{array}$ & $\begin{array}{l}\text { seksualność } \\
\text { wyrażana } \\
\text { w rozumieniu } \\
\text { intymności }\end{array}$ & $\begin{array}{l}\text { seksualność } \\
\text { jako potrzeba } \\
\text { fizycznego } \\
\text { rozładowania } \\
\text { związana } \\
\text { ze wstydem }\end{array}$ \\
\hline
\end{tabular}

Źródło: Opracowanie własne.

\section{Zamiast zakończenia}

Seksualność stanowi jeden z najważniejszych aspektów życia człowieka, odnosi się do płci, identyfikacji, roli płciowej, orientacji seksualnej, erotyki, przyjemności, intymności. Spełnia funkcję prokreacyjną, hedonistyczną, więziotwórczą, a także tworzy integralną składową osobowości kobiet i mężczyzn. Seksualność człowieka obejmuje zatem pięć głównych obszarów: rozwój fizyczny, psychiczny, socjalny i intelektualny, zdrowie seksualne, relacje interpersonalne i emocje [Kijak 2011, s.141]. W kontekście niepełnosprawności intelektualnej, można mówić o jej 
zmienionym doświadczaniu, nie zaś o nieistnieniu, co zobrazować miały przeprowadzone badania.

W refleksjach o potrzebie edukowania w zakresie seksualności, "oswajania” jej, nie może zabraknąć miejsca na uwzględnienie środowiska dorosłych osób z niepełnosprawnością intelektualną, jej dostępności dla nich, stwarzaniu możliwości do realizowania potrzeb psychoseksualnych. „Okazuje się, że to nie osoba niepełnosprawna nie daje rady sobie z dorosłością, lecz system, jaki na potrzeby opieki nad nią stworzyliśmy. System, w którym brakuje zarówno odwagi i wyobraźni dla promowania samodzielności i autonomii dorosłości, jak i środków dla kosztownych inicjatyw wchodzących w życie, jest niewydolny. Na to nakładają się oczywiście ogólne problemy z seksualnością w Polsce" [Krause, 2009, s. 16].

\section{Bibliografia}

Bartoszek A. (2009), Seksualność osób niepetnosprawnych: studium teologiczno-moralne, Księgarnia św. Jacka, Katowice.

Buchnat M., Waszyńska K. (2014), Edukacja seksualna osób z lekkg niepetnosprawnościa intelektualna w systemie szkolnym, t.12, „Seksuologia Polska”, nr 2, s. 43-50.

Fornalik I. (2002), Potrzeby osób z niepetnosprawnościq intelektualna w okresie adolescencji a możliwość ich realizacji [w:] Pedagogika specjalna szansa na realizację potrzeb osób z odchyleniami od normy, W. Dykcik, Cz. Kosakowski, J. Kuczyńska-Kwapisz (red.), Wydawnictwo Naukowe PTP Oddział w Poznaniu, Olsztyn-Poznań-Warszawa.

Fornalik I. (2012), Edukacja osób z niepetnosprawnościq̨ intelektualna. W poszukiwaniu wtaścizego modelu [w:] Przemiany seksualności w społeczeństwie wspótczesnym. Teoria i rzeczywistość, Z. Lew-Starowicz, K. Waszyńska (red.), Wydawnictwo Naukowe UAM, Poznań.

Jaczewski A., Radomski J. (1986), Wychowanie seksualne i problemy seksuologiczne wieku rozwojowego, Państwowy Zakład Wydawnictw Lekarskich, Warszawa.

Janiszewska-Nieścioruk Z. (2013), Respektowanie i egzekwowanie praw seksualnych osób z niepetnosprawnościq - palacy, nierozwiazzany problem [w:] Człowiek z niepetnosprawnościa w rezerwacie przestrzeni publicznej, Z. Gajdzica (red.), Oficyna Wydawnicza „Impuls”, Kraków.

Kijak R., (2010), Problematyka seksualności osób z niepetnosprawnościa intelektualna w stopniu umiarkowanym - prawidtowości rozwoju oraz kontekst społeczny [w:] Dzieci i młodzież ze specjalnymi potrzebami edukacyjnymi w realizacji zadan rozwojowych, B. Witkowska, K. Bidziński, P. Kurtek (red.), Wydawnictwo UHP, Kielce.

Kijak R. (2011), W stronę rozumienia seksualności osób z gtębsza niepetnosprawnością intelektualna, „Forum Oświatowe”, nr 1, s. 137-151.

Kijak R. (2014), Seksualność cztowieka z niepetnosprawnościq intelektualna a rodzina, Wydawnictwo Lekarskie PZWL, Warszawa.

Kościelska M. (2004), Niechciana seksualność. O ludzkich potrzebach osób niepetnosprawnych intelektualnie, Wydawnictwo Jacek Santorski \& Co., Warszawa.

Krause A. (2009), Teoretyczne i empiryczne problemy pedagogiki specjalnej. Zarys obszarów badawczych, „Niepełnosprawność", nr 1, s. 10-24. 
Krause A. (2010), Wspótczesne paradygmaty pedagogiki specjalnej, Oficyna Wydawnicza „Impuls", Kraków.

Leutar Z., Mihokovic M. (2007), Level of knowledge about sexuality of people with mental disabilities, "Sexuality and Disability", nr 25(3), s. 93-109.

Marton F. (1986), Phenomenography: A Research Approach to Investigating Different Understandings of Reality, t. 21, "Journal of Thought", nr 3, s. 28-49.

McCarthy M., Thomson D. (1997), A prevalence study of sexual abuse of adulds with inellectual disabilities referred for sex education, t. 10, "Journal of Applied Research in Intellectual Disabilities", nr 2, s. 105-124.

McGillivray J. A. (1999), Level of Knowledge and Risk of Contracting HIV/AIDS Amongst Young Adults with Mild/Moderate Intellectual Disability, t. 12, „Journal of Applied Research in Intellectual Disabilities", nr 2, s. 113-126.

Mejnartowicz D. (2002), Seksualność osób z zespotem Downa [w:] Wieczne dzieci czy dorośli. Problem seksualności osób z niepetnosprawnością intelektualnq, J. Graban (red.), Stowarzyszenie Rodzin i Opiekunów Osób z Zespołem Downa „Bardziej kochani”, Warszawa.

Pilch T., Bauman T. (2001), Zasady badań pedagogicznych. Strategie ilościowe i jakościowe, Wydawnictwo akademickie Żak, Warszawa.

Standardy edukacji seksualnej w Europie (2012), tłum. M. Sikorska-Janoszyńska, B. Balińska, E. Pieszczyk, A. Wiewióra, Wydawnictwo Czelej Sp. z o.o., Lublin. 